\title{
Article \\ Comparison of Alum and Sulfuric Acid to Retain and Increase the Ammonium Content of Digestate Solids during Thermal Drying
}

\author{
Jingna Liu ${ }^{1,2}$, Lars Stoumann Jensen ${ }^{2}$ (D) and Dorette Sophie Müller-Stöver ${ }^{2, *}$ \\ 1 School of Agriculture, Sun Yat-Sen University, Shenzhen 518107, China; liu@plen.ku.dk \\ 2 Department of Plant and Environmental Science, Faculty of Science, University of Copenhagen, \\ 1871 Frederiksberg, Denmark; 1sj@plen.ku.dk \\ * Correspondence: dsst@plen.ku.dk
}

Citation: Liu, J.; Jensen, L.S.;

Müller-Stöver, D.S. Comparison of

Alum and Sulfuric Acid to Retain and Increase the Ammonium Content of Digestate Solids during Thermal Drying. Nitrogen 2021, 2, 287-297. https://doi.org/10.3390/

nitrogen 2020019

Academic Editor: Germán Tortosa

Received: 7 April 2021

Accepted: 3 June 2021

Published: 10 June 2021

Publisher's Note: MDPI stays neutral with regard to jurisdictional claims in published maps and institutional affiliations.

Copyright: (c) 2021 by the authors. Licensee MDPI, Basel, Switzerland. This article is an open access article distributed under the terms and conditions of the Creative Commons Attribution (CC BY) license (https:// creativecommons.org/licenses/by/ $4.0 /)$.

\begin{abstract}
Aluminum sulphate (alum, $\mathrm{Al}_{2}\left(\mathrm{SO}_{4}\right)_{3} \cdot n \mathrm{H}_{2} \mathrm{O}$ ) has successfully been used to reduce ammonia loss from poultry litter, cattle feedlots and manure composting, but has not yet been utilized in the thermal drying process of digestate solids. The objectives of the present study were to evaluate the effects of alum addition on ammonium nitrogen $\left(\mathrm{NH}_{4}{ }^{+}-\mathrm{N}\right)$ content and phosphorus (P) solubility in dried digestate solids in comparison to the addition of concentrated sulfuric acid $\left(\mathrm{H}_{2} \mathrm{SO}_{4}\right)$. Manure-based (MDS) and sewage sludge-based (SDS) digestate solids were chosen to conduct a drying experiment at four $\mathrm{pH}$ levels (original $\mathrm{pH}, 8.0,7.5$ and 6.5) and using two acidifying agents (alum, concentrated $\mathrm{H}_{2} \mathrm{SO}_{4}$ ). Alum addition increased the final $\mathrm{NH}_{4}{ }^{+}-\mathrm{N}$ content significantly from $1.4 \mathrm{mg} \mathrm{g}^{-1}$ in the non-acidified control up to $18 \mathrm{mg} \mathrm{g}^{-1}$ and $10.8 \mathrm{mg} \mathrm{g}^{-1}$ in dried MDS and SDS, respectively, which were higher levels than obtained with the addition of concentrated $\mathrm{H}_{2} \mathrm{SO}_{4}$. Moreover, alum considerably lowered the water extractable phosphorus (WEP) in raw and dried SDS by $37-83 \%$ and $48-72 \%$, respectively, compared with the non-treated control. In contrast, concentrated $\mathrm{H}_{2} \mathrm{SO}_{4}$ notably increased WEP in raw and dried MDS by $18-103 \%$ and $29-225 \%$, respectively. The comparison between the two acidifying agents indicated that alum had the potential to be an efficient and easy-handling alternative to concentrated sulfuric acid, resulting in higher $\mathrm{NH}_{4}{ }^{+}-\mathrm{N}$ content and lower P solubility.
\end{abstract}

Keywords: aluminum sulfate; ammonia loss; acidification; thermal drying; biosolids

\section{Introduction}

Anaerobic digestion is a well-established waste-to-energy technology for treatment of various organic wastes, which also facilitates recycling of valuable nutrient resources like nitrogen $(\mathrm{N})$ and phosphorus $(\mathrm{P})$ in the waste materials [1]. However, the high volume and low nutrient concentrations of the digested effluent make it difficult and costly to utilize. Thermal drying of the dewatered effluent from anaerobic digesters (digestate solids) is an effective post-treatment process for volume reduction and stabilization [2,3]. Unfortunately, up to $95 \%$ of the $\mathrm{NH}_{4}{ }^{+}-\mathrm{N}$ contained in the solids can be emitted as $\mathrm{NH}_{3}$ during the drying treatment [4] due to the high $\mathrm{pH}(>8.0)$ of the digestate solids and the high temperature $\left(>70^{\circ} \mathrm{C}\right)$ of the drying process. To avoid these massive $\mathrm{N}$ losses and improve the fertilizer value of the dried products, concentrated sulfuric acid can be used to acidify the digestate solids before drying [4]. However, special equipment and operation skills are required when handling acids to avoid corrosion of farm installation systems and potential hazards to the health of farm animals and farmers. Furthermore, Roboredo et al. (2012) [5] and Sommer et al. (2015) [6] reported that acidification using concentrated sulfuric acid increased water soluble $\mathrm{P}$ in the solid fraction of pig slurry, resulting in a higher risk of $\mathrm{P}$ leaching and runoff. 
Aluminum sulphate $\left(\mathrm{Al}_{2}\left(\mathrm{SO}_{4}\right)_{3} \cdot n \mathrm{H}_{2} \mathrm{O}\right)$, commonly referred to as alum, has been suggested as a practical and economical amendment to reduce ammonia emissions from poultry litter [7], cattle feedlots [8] and animal manure composting [9]. Alum hydrolyzes to the aluminum hydroxide precipitate and a dilute sulfuric acid solution [10], resulting in lower $\mathrm{pH}$ of the mixture and thus conserving $\mathrm{N}$ in $\mathrm{NH}_{4}{ }^{+}$form to avoid volatilization losses.

In trials conducted in poultry or cattle farming, alum was generally applied at a rate of $2-10 \%$ of the weight of poultry litter or cattle feedlot surface material and caused $70-99 \%$ lower $\mathrm{NH}_{3}$ losses than the untreated control $[8,11,12]$. In manure composting studies, $2.5-10 \%$ alum addition reduced $\mathrm{NH}_{3}$ volatilization by $58-85 \%[9,13,14]$. Furthermore, Moore and Edwards (2007) [15] and Huang et al. (2016) [16] indicated that inorganic and organic $\mathrm{P}$ compounds in poultry litter react with $\mathrm{Al}$ from alum, leading to lower $\mathrm{P}$ solubility and thus resulting in significantly reduced risk for P runoff and leaching after soil application. Therefore, alum has the potential to be an alternative acidifying agent with lower risks of operation safety and P eutrophication. However, alum has not yet been utilized as an acidifying agent in the thermal drying process of digestate solids.

The overall objective of the present study was therefore to evaluate (i) the efficiency of alum as an acidifying agent to retain $\mathrm{NH}_{4}{ }^{+}-\mathrm{N}$ in digestate solids during thermal drying and (ii) P solubility in alum-treated thermally-dried solids.

It was hypothesized that:

(1) Alum increases the ammonium nitrogen content after thermal drying of digestate solids to the same extent as concentrated $\mathrm{H}_{2} \mathrm{SO}_{4}$;

(2) Alum-treated thermally-dried digestate solids have a lower P solubility than the non-treated dried solids;

(3) $\mathrm{H}_{2} \mathrm{SO}_{4}$-treated thermally-dried digestate solids have a higher $\mathrm{P}$ solubility than the nontreated dried solids, and $\mathrm{P}$ solubility is positively correlated with the acidification level.

\section{Materials and Methods}

\subsection{Digestate Solids}

Two kinds of digestate solids derived from anaerobic digestion of either manure (MDS-70\% dairy, 20\% pig, 8-9\% chicken manure and 1-2\% food waste) or sewage sludge (SDS-the secondary sludge after chemical removal of $\mathrm{P}$ using $\mathrm{ClFeO}_{4} \mathrm{~S}$ and sludge precipitation with $\mathrm{AlCl}_{3}$ ) were freshly collected from Morsø biogas plant (Mors, Denmark) and Bjergmarken wastewater treatment plant (Roskilde, Denmark), respectively. Sampling was conducted directly at the outlet of the mechanical solid-liquid separator (decanting centrifuge). MDS and SDS were kept frozen at $-20{ }^{\circ} \mathrm{C}$ after collection and the required amount was defrozen at room temperature overnight before further use. The main characteristics of the MDS and SDS are shown in Table 1.

Table 1. Chemical characteristics of manure-based digestate solids (MDS) and sewage sludge-based digestate solids (SDS) used in the experiments.

\begin{tabular}{|c|c|c|c|c|c|c|c|c|c|c|c|c|}
\hline Material & $\begin{array}{c}\text { Dry Matter } \\
\text { Content (DM) }\end{array}$ & $\mathrm{pH}$ & $\mathrm{NH}_{4}{ }^{+}-\mathrm{N}$ & $\mathrm{N}_{\text {tot }}$ & $P_{\text {tot }}$ & $K_{\text {tot }}$ & $\mathrm{Ca}_{\text {tot }}$ & $\mathrm{Al}_{\text {tot }}$ & $\mathbf{M g}_{\text {tot }}$ & $\mathrm{C} / \mathrm{N}$ & $\mathrm{Ca} / \mathrm{P}$ & $\mathbf{A} 1 / \mathbf{P}$ \\
\hline & $\%$ & & & & & $-\mathrm{g} \cdot \mathrm{kg}^{-}$ & $\mathrm{DM}$ & 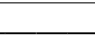 & - & & & \\
\hline MDS & 27.3 & 9.2 & 7.7 & 39.4 & 25.9 & 10.5 & 35 & 1.3 & 14.4 & 11.3 & 1.4 & 0.05 \\
\hline SDS & 27 & 8.6 & 8.9 & 44 & 36 & 2.8 & 64 & 13.5 & 7.4 & 6.8 & 1.8 & 0.4 \\
\hline
\end{tabular}

\subsection{Experimental Procedure}

Drying experiments using MDS and SDS were conducted in a laboratory-scale drying system placed in a laboratory oven, as described in detail in [17]. Drying was operated at a temperature of $130{ }^{\circ} \mathrm{C}$ and an air ventilation rate of $525 \mathrm{~mL} \mathrm{~min}^{-1}$, corresponding to a headspace exchange rate of 286 times hour $^{-1}$. Before drying, caking was removed 
from the fibrous MDS material and the sticky SDS material was cut into rectangular blocks $(1 \times 1 \times 2.8 \mathrm{~cm}$, around $4.5 \mathrm{~g}$ per block) to ensure homogeneity of drying time.

In a preliminary experiment, the time for drying was estimated by drying raw MDS/SDS to a DM content of 85\% (MDS $200 \mathrm{~min}$ and SDS $170 \mathrm{~min}$ ) and divided equally into four periods (T1-T4). Furthermore, a titration curve was established to determine the amount of alum required to decrease the $\mathrm{pH}$ of MDS and SDS to the targeted levels. MDS/SDS was homogeneously mixed with alum and kept at room temperature for $72 \mathrm{~h}$ to investigate the evolution of $\mathrm{pH}$ before the determination of the titration curve. The titration curve for concentrated $\mathrm{H}_{2} \mathrm{SO}_{4}$ had already been established in a prior study [17].

In the final experiment, two varying factors were applied to MDS/SDS: (a) initial $\mathrm{pH}$ before drying (acidified to $\mathrm{pH}$ 8.0, 7.5 or 6.5, respectively) and (b) acidification agents (concentrated sulfuric acid (95-97\% $\mathrm{H}_{2} \mathrm{SO}_{4}$, EMPARTA, Darmstadt, Germany) and alum $\left(99.99 \%, \mathrm{Al}_{2}(\mathrm{SO} 4)_{3}\right.$, Sigma-Aldrich, Saint Louis, Missouri, USA). In total, seven treatments were established for one material (one non-acidified control, three treatments acidified using concentrated $\mathrm{H}_{2} \mathrm{SO}_{4}$ to reach the initial $\mathrm{pH}$ levels, and three treatments acidified using alum to reach the initial $\mathrm{pH}$ levels). The final amounts added to each material can be found in Table 2. MDS and SDS samples for each acidification level with concentrated $\mathrm{H}_{2} \mathrm{SO}_{4}$ were freshly prepared before drying as described in Liu et al. (2019) [17]. For alum, a $24 \mathrm{~h}$ premix with the materials was performed (see Section 3 for rationale).

Table 2. Application rate (based on fresh weight of digestate solids) of acidifying agents.

\begin{tabular}{|c|c|c|c|c|c|}
\hline \multicolumn{2}{|c|}{ Acidification Level } & pH Original & pH 8.0 & pH7.5 & pH 6.5 \\
\hline \multicolumn{2}{|c|}{ application rate } & & & & \\
\hline \multirow{2}{*}{ MDS } & $\mathrm{H}_{2} \mathrm{SO}_{4} \mu \mathrm{Lg}^{-1}$ & 0 & 5 & 7.5 & 12.5 \\
\hline & alum \% & 0 & 1.2 & 2 & 4 \\
\hline \multirow{2}{*}{ SDS } & $\mathrm{H}_{2} \mathrm{SO}_{4} \mu \mathrm{Lg}^{-1}$ & 0 & 1.25 & 2.5 & 5 \\
\hline & alum \% & 0 & 0.8 & 1.3 & 3 \\
\hline
\end{tabular}

Triplicate samples stayed in the oven (at $130{ }^{\circ} \mathrm{C}$ ) for one, two, three or four drying periods (T1-T4), respectively. Before further measurements, samples were removed and placed in a desiccator until they had reached room temperature (around $15 \mathrm{~min}$ ). Afterwards, samples were weighed and $\mathrm{pH}$ was measured with a PHM 210 Standard $\mathrm{pH}$ Meter (Radiometer Analytical, Lyon, France) using a 1:5 (dw/v) ratio of solids to deionized water.

MDS/SDS $\mathrm{NH}_{4}{ }^{+}-\mathrm{N}$ contents from different drying time points were analyzed after extraction with $1 \mathrm{M} \mathrm{KCl}(1: 20, d w / v$, shaking for $45 \mathrm{~min}$ on an end-over-end shaker and filtering through Whatman no.5 filter paper) using flow-injection analysis (FIAstar 5000 Analyzer, FOSS, Hilleroed, Denmark). Water extractable phosphorus (WEP) contents from initial and final drying time points were measured after extraction with deionized water (1:100,dw/v), shaking for $1 \mathrm{~h}$ and filtering through Whatman no.5 filter paper) using flow-injection analysis.

\subsection{Statistical Analyses}

Statistical analyses of drying curve, $\mathrm{pH}$ variation and $\mathrm{NH}_{4}{ }^{+}-\mathrm{N}$ content during the thermal drying process were conducted using a one-way ANOVA followed by the Tukey test at the 0.05 significance level. For all ANOVAs, the assumption of the homogenous variance of different groups was checked with Levene's test and the assumption of normality was tested using the Kolmogorov-Smirnov test. All statistical analyses were conducted using IBM SPSS Statistics 22 (Armonk, New York, NY, USA).

\section{Results and Discussion}

\subsection{Alum Titration Curve}

According to the $\mathrm{pH}$ evolution test of MDS and SDS for $72 \mathrm{~h}$ after alum addition (Figure 1), the $\mathrm{pH}$ decline could be divided into three stages: I, precipitous decline stage, 
instantly after alum addition; II, slow decline stage, 0-24 h, and III, relatively stable stage, after $24 \mathrm{~h}$ upon addition. In MDS, most of the $\mathrm{pH}$ decline (from 9.1 to 7.9) happened in stage I, and $\mathrm{pH}$ remained at around 7.8 after $24 \mathrm{~h}$ upon addition. For SDS, $\mathrm{pH}$ dropped from 8.6 to 7.1 in stage I and gradually declined to 6.4 in stage II. Therefore, MDS and SDS were homogeneously mixed with alum and kept at room temperature for $24 \mathrm{~h}$ before titration curve measurement.

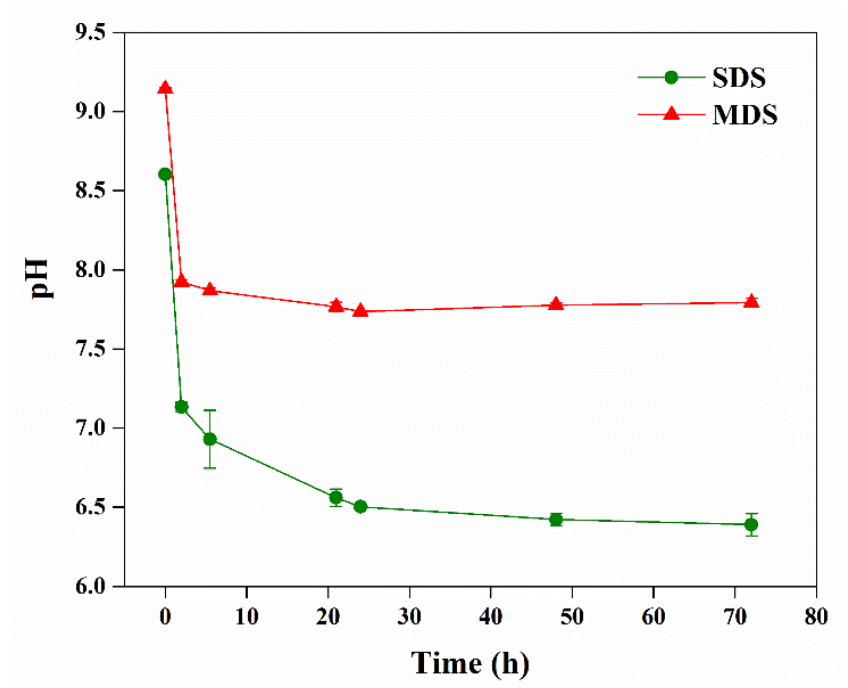

Figure 1. $\mathrm{pH}$ evolution pattern of manure-based (MDS) and dewatered sewage sludge-based (SDS) digestate solids after adding $4 \%$ (MDS) and $\%$ (SDS) alum, respectively.

We tested the alum titration curve based on two time points for MDS: I, $24 \mathrm{~h}$ after alum addition; II, $50 \mathrm{~min}$ after drying at $130{ }^{\circ} \mathrm{C}$ (Figure 2), since in the following thermal drying test, MDS and SDS were observed to have different $\mathrm{pH}$ variation patterns in response to alum addition. The $\mathrm{pH}$ of alum-treated MDS dramatically declined while drying, yet $\mathrm{pH}$ of SDS remained stable. An excessive amount of alum (15\%, wet weight based) was used to acidify raw MDS to $\mathrm{pH}$ 6.5, but $\mathrm{pH}$ dropped to 3.8 after 50 min drying (Figure 2). Therefore, the time point II titration curve was chosen for the determination of the necessary amount of alum to be used to acidify MDS. Table 2 shows the required amount of alum to adjust the $\mathrm{pH}$ of MDS and SDS from the starting value to $\mathrm{pH} 8.0,7.5$ and 6.5, respectively.

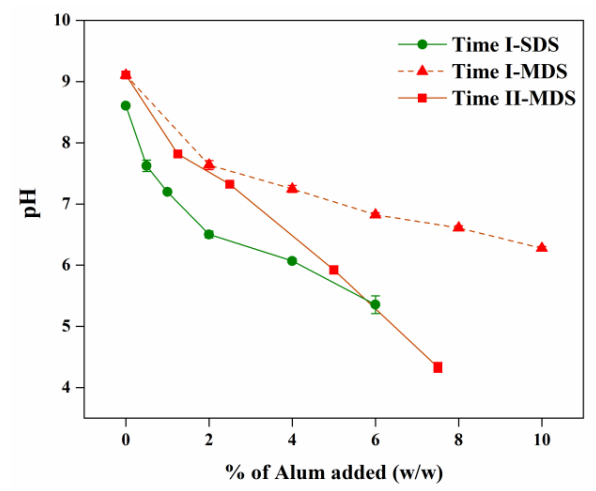

Figure 2. Titration curves of the manure-based (MDS) and dewatered sewage sludge-based (SDS) digestate solids. Error bars represent standard error $(n=3)$ (Testing time, I: $24 \mathrm{~h}$ after alum addition, before drying, II: after $50 \mathrm{~min}$ drying at $130^{\circ} \mathrm{C}$ ).

The different $\mathrm{pH}$ variation patterns between the two solids during drying were possibly due to the different physical structure of the two materials resulting in a different hydrolysis time of alum. Alum may have hydrolyzed more readily in SDS than in MDS, and a continuous $\mathrm{pH}$ decline occurred between $0-24 \mathrm{~h}$ after alum addition (Figure 1). 
Since alum was applied as powder, the compact and sludgy SDS probably benefited the solid-liquid reactions by providing a large contact area, which led to a considerable rate of hydrolysis. MDS had a more fibrous, porous structure, possibly resulting in non-sufficient contact with a lower rate of hydrolysis during premix (24 h).

\subsection{Drying Curve}

For MDS and SDS, drying curve patterns under acidification using concentrated $\mathrm{H}_{2} \mathrm{SO}_{4}$ bore strong similarities to the treatments using alum across all acidification levels (Figure $3 \mathrm{a}, \mathrm{b}$ and Figure $4 \mathrm{a}, \mathrm{b}$ ). The moisture content declined almost linearly with drying time.
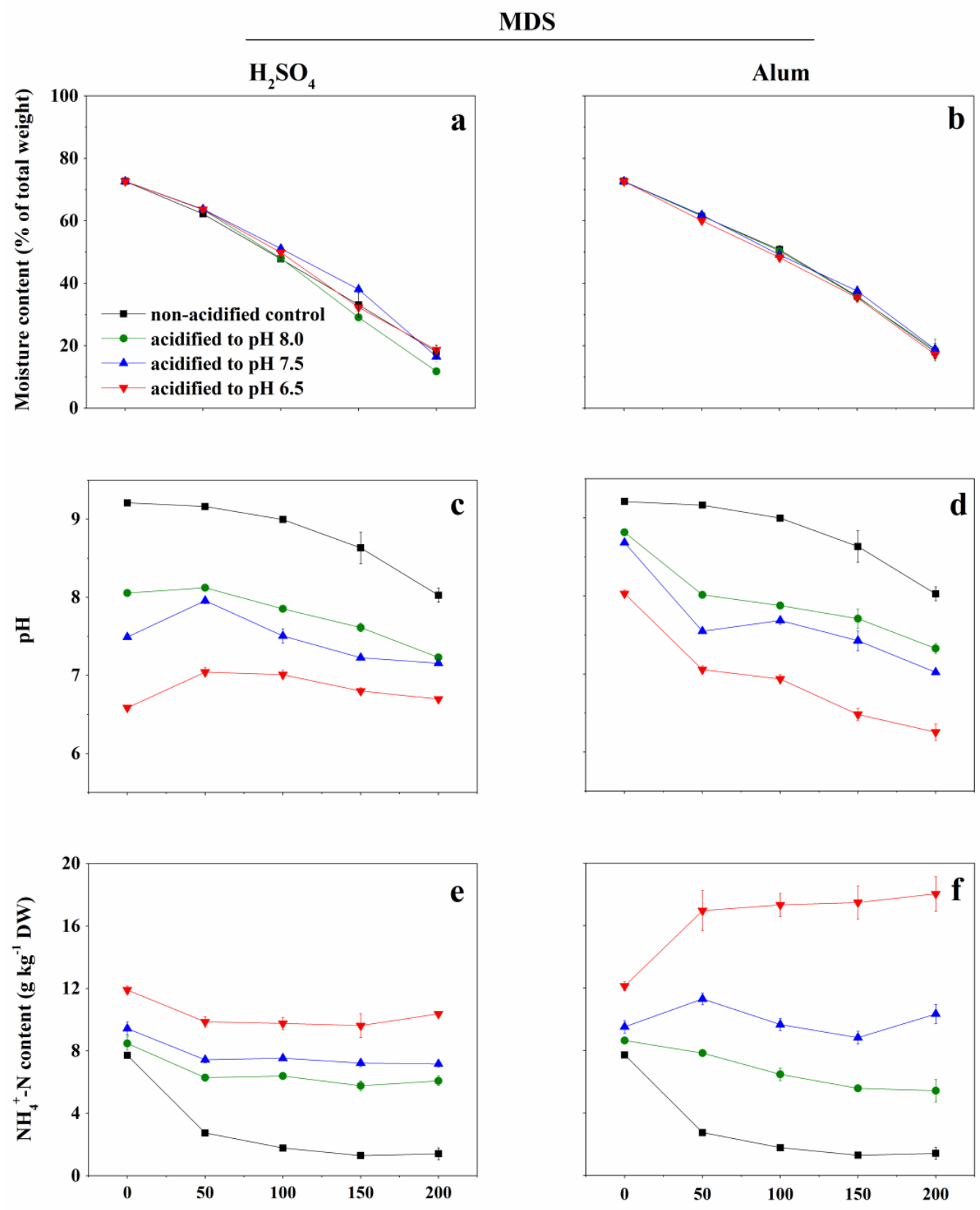

Drying time (min)

Figure 3. Moisture loss (a,b), $\mathrm{pH}$ evolution (c,d) and $\mathrm{NH}_{4}{ }^{+}-\mathrm{N}$ content $(\mathbf{e}, \mathbf{f})$ of the manure-based digestate solids (MDS) during thermal drying (ventilated, $130{ }^{\circ} \mathrm{C}$ ) in the non-acidified control (original $\mathrm{pH}$ ) and acidified to three different $\mathrm{pH}$ levels with $\mathrm{H}_{2} \mathrm{SO}_{4}$ (left) or alum (right). Error bars represent standard error $(n=3)$; when not visible, error bars are covered by symbols. 


\section{SDS}
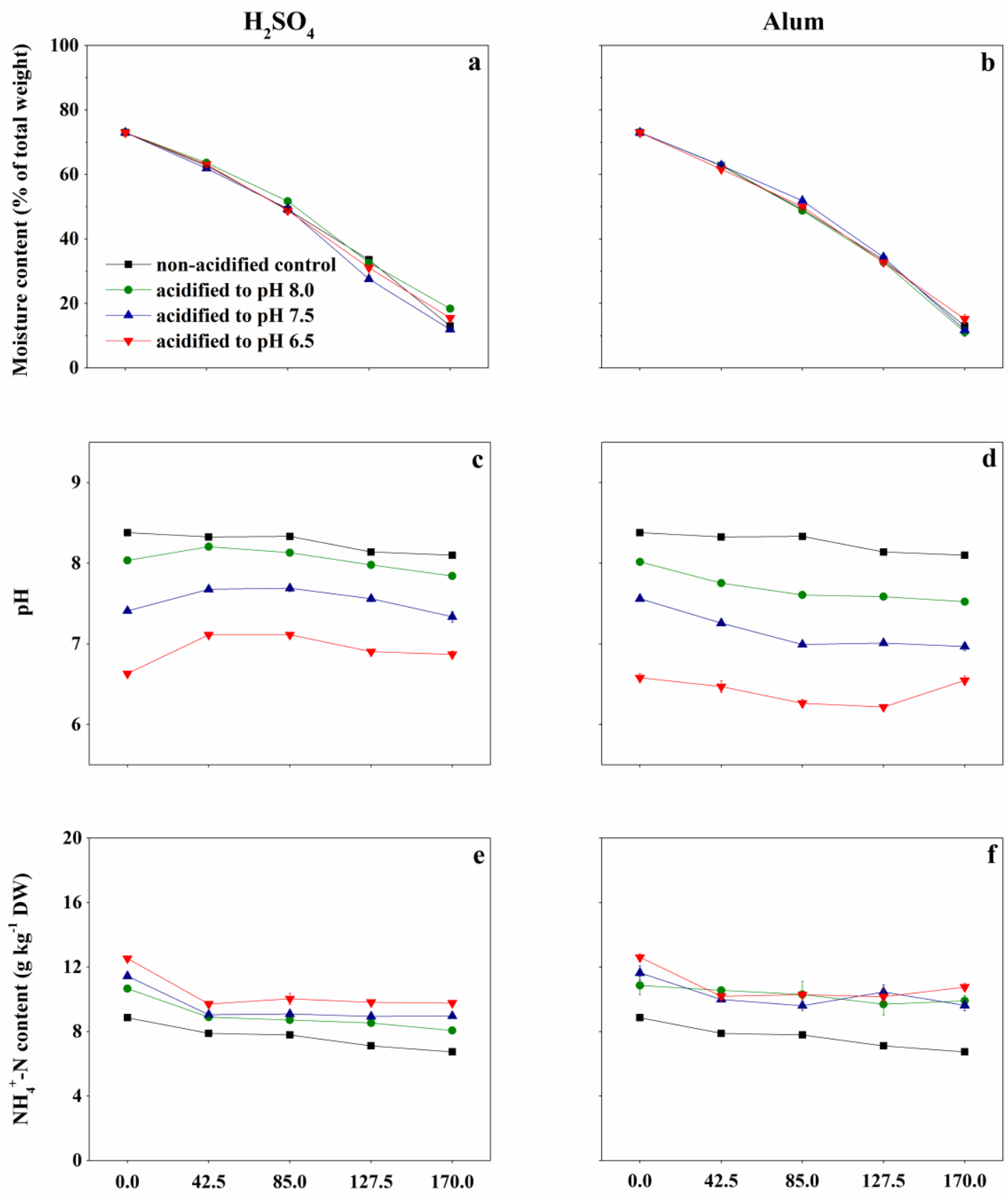

\section{Drying time (min)}

Figure 4. Moisture loss $(\mathbf{a}, \mathbf{b}), \mathrm{pH}$ evolution $(\mathbf{c}, \mathbf{d})$ and $\mathrm{NH}_{4}{ }^{+}-\mathrm{N}$ content $(\mathbf{e}, \mathbf{f})$ of the sewage sludge-based digestate solids (SDS) during thermal drying (ventilated, $130^{\circ} \mathrm{C}$ ) in the non-acidified control (original $\mathrm{pH}$ ) and acidified to three different $\mathrm{pH}$ levels with $\mathrm{H}_{2} \mathrm{SO}_{4}$ (left) or alum (right). Error bars represent standard error $(n=3)$; when not visible, error bars are covered by symbols.

\section{3. $p H$ Evolution during Drying}

MDS and SDS showed similar $\mathrm{pH}$ evolution patterns upon addition of concentrated sulfuric acid, peaking at T1 and descending later with a variation range of 0.5 and 0.2 units in MDS and SDS, respectively (Figures 3a and 4a). As already pointed out in a previous study [17], this could be attributed to the release of the $\mathrm{CO}_{2}$ from dissolved bicarbonate of digestate solids resulting in a net increase of $\mathrm{pH}$ at $\mathrm{T} 1$ [18], and to the subsequent release of 
$\mathrm{H}^{+}$from dissociation of $\mathrm{NH}_{4}{ }^{+}$to $\mathrm{NH}_{3}$ after bicarbonate depletion, contributing to the later $\mathrm{pH}$ decline.

In MDS treated with alum, the $\mathrm{pH}$ declined by approximately 1 unit in $\mathrm{T} 1$ and then gradually decreased around 0.5 units within $\mathrm{T} 2-4$. In contrast, $\mathrm{pH}$ did not show a significant decline in SDS during T1, but a mild decrease of $\mathrm{pH}$, around 0.5 units, occurred with drying. As alum hydrolysis is strongly temperature-dependent [19], high temperature and intensified water movement during drying [20] probably promoted the alum hydrolysis, contributing to the sharp decrease of $\mathrm{pH}$ in alum-treated MDS (Figure 3d). Thus we hypothesize that alum hydrolysis mainly occurred during the $24 \mathrm{~h}$ premix in SDS and during the drying process in MDS, respectively.

\section{4. $\mathrm{NH}_{4}{ }^{+}-\mathrm{N}$ Content in the Materials during Drying}

Acidification significantly increased $(p<0.05)$ the initial $\mathrm{NH}_{4}{ }^{+}-\mathrm{N}$ contents irrespective of the acidifying agents, possibly due to acid-induced hydrolysis of the solids' organic matter [21]. For MDS, the initial $\mathrm{NH}_{4}{ }^{+}-\mathrm{N}$ content was increased from $7.7 \mathrm{mg} \mathrm{g}^{-1}$ to 8.6, 9.5 and $12.0 \mathrm{mg} \mathrm{g}^{-1}$ at target acidification levels of $\mathrm{pH}$ 8.0, 7.5 and 6.5, respectively (Figure 3a,b). Similarly, the initial $\mathrm{NH}_{4}{ }^{+}-\mathrm{N}$ content of SDS was raised from $8.9 \mathrm{mg} \mathrm{g}^{-1}$ to $10.8,11.5$ and $12.6 \mathrm{mg} \mathrm{g}^{-1}$ (Figure 4e,f).

For MDS, the variation patterns of $\mathrm{NH}_{4}{ }^{+}-\mathrm{N}$ contents during thermal drying were different between acidification agents (Figure $3 e, f$ ). When using concentrated $\mathrm{H}_{2} \mathrm{SO}_{4}$, $\mathrm{NH}_{4}{ }^{+}-\mathrm{N}$ declined in $\mathrm{T} 1$, probably due to ammonia volatilization from the high initial $\mathrm{NH}_{4}{ }^{+}-\mathrm{N}$ content. Pantelopoulos et al. (2016) [4] also reported that more than $90 \%$ of the total $\mathrm{NH}_{4}{ }^{+}-\mathrm{N}$ content decline in digestate solids occurred during the early stage of drying at $70-160^{\circ} \mathrm{C}$. In contrast, when acidifying MDS using alum (to $\mathrm{pH} 7.5$ and 6.5), a significant increase of $\mathrm{NH}_{4}{ }^{+}-\mathrm{N}$ was seen at $\mathrm{T} 1$, which was probably due to the $\mathrm{pH}$-induced further hydrolysis of organic $\mathrm{N}$. During the drying process, a considerable decrease of $\mathrm{pH}$ occurred because of alum hydrolysis (Figure 4d). Acidification using both agents significantly increased $(p<0.05)$ the $\mathrm{NH}_{4}{ }^{+}-\mathrm{N}$ content compared to the control, however, alum addition induced a higher $\mathrm{NH}_{4}{ }^{+}-\mathrm{N}$ content than concentrated $\mathrm{H}_{2} \mathrm{SO}_{4}$ at each acidification level (Figure 5a).

The different $\mathrm{NH}_{4}{ }^{+}-\mathrm{N}$ contents at each sampling time (T1-T4) were the net balance between hydrolysis of organic $\mathrm{N}$ and $\mathrm{NH}_{3}$ volatilization losses. Since $\mathrm{NH}_{3}$ volatilization was not directly measured, no conclusion can be drawn with regard to the total $\mathrm{N}$ balance of the acidifying and drying processes.

Many previous studies concerning the reduction of $\mathrm{NH}_{3}$ emissions from animal manure and slurry documented the efficiency of concentrated $\mathrm{H}_{2} \mathrm{SO}_{4}[21$,22]. Regarding alum, Bautista et al. (2011) [9] reported that $\mathrm{NH}_{3}$ emissions from swine manure treated with $2.5 \%$ alum were, on average, $84 \%$ lower than those from the control during 18 days of composting. Spiehs and Woodbury (2018) [8] reported that acidifying beef feedlots to below $\mathrm{pH} 6.5$ using alum could completely suppress $\mathrm{NH}_{3}$ emissions. Early reports also linked reduction of ammonia losses directly to the final $\mathrm{pH}$ after acidification [23,24]. Similarly, the present study indicated that the increase of $\mathrm{NH}_{4}{ }^{+}-\mathrm{N}$ content in dried digestate solids became more pronounced with the increasing acidification level (Figure 5a). Acidifying MDS to $\mathrm{pH} 6.5$ using $\mathrm{H}_{2} \mathrm{SO}_{4}$ and alum achieved $34 \%$ and $134 \%$ higher $\mathrm{NH}_{4}{ }^{+}-\mathrm{N}$ content in the final dried MDS, respectively, relative to the initial $\mathrm{NH}_{4}{ }^{+}-\mathrm{N}$ content $\left(7.7 \mathrm{mg} \mathrm{g}^{-1}\right)$ in the control (Figure 5a).

Regarding SDS, at drying, comparable $\mathrm{NH}_{4}{ }^{+}-\mathrm{N}$ content variation patterns were observed with the two acidification agents: almost all the $\mathrm{NH}_{4}{ }^{+}-\mathrm{N}$ decline occurred in $\mathrm{T} 1$ and then $\mathrm{NH}_{4}{ }^{+}-\mathrm{N}$ content of SDS maintained stable. As mentioned above, alum may undergo a high hydrolysis rate during the $24 \mathrm{~h}$ premix period in SDS, resulting in a lower $\mathrm{pH}$ decrease during drying compared to MDS. Therefore, acid-induced hydrolysis of SDS organic matter might only happen before drying and the $\mathrm{NH}_{4}{ }^{+}-\mathrm{N}$ content of SDS did not increase during drying as observed for the alum-treated MDS. Although the relative $\mathrm{NH}_{4}{ }^{+}-\mathrm{N}$ content reduction in the non-acidified SDS control was much less than for MDS, 
acidification using concentrated $\mathrm{H}_{2} \mathrm{SO}_{4}$ and alum also significantly enhanced $(p<0.05)$ the $\mathrm{NH}_{4}{ }^{+}-\mathrm{N}$ content in the final dried SDS (Figure $5 \mathrm{~b}$ ). After drying, alum-treated SDS had a higher $\mathrm{NH}_{4}{ }^{+}-\mathrm{N}$ content than $\mathrm{H}_{2} \mathrm{SO}_{4}$-treated SDS (Figure $5 \mathrm{~b}$ ). In particular, SDS acidified to $\mathrm{pH} 8.0$ using alum already had a $12 \%$ higher $\mathrm{NH}_{4}{ }^{+}-\mathrm{N}$ content relative to the initial content $\left(8.9 \mathrm{mg} \mathrm{g}^{-1}\right)$ in the control, while a $9 \%$ lower $\mathrm{NH}_{4}{ }^{+}-\mathrm{N}$ content was achieved by using concentrated $\mathrm{H}_{2} \mathrm{SO}_{4}$ relative to the initial content.
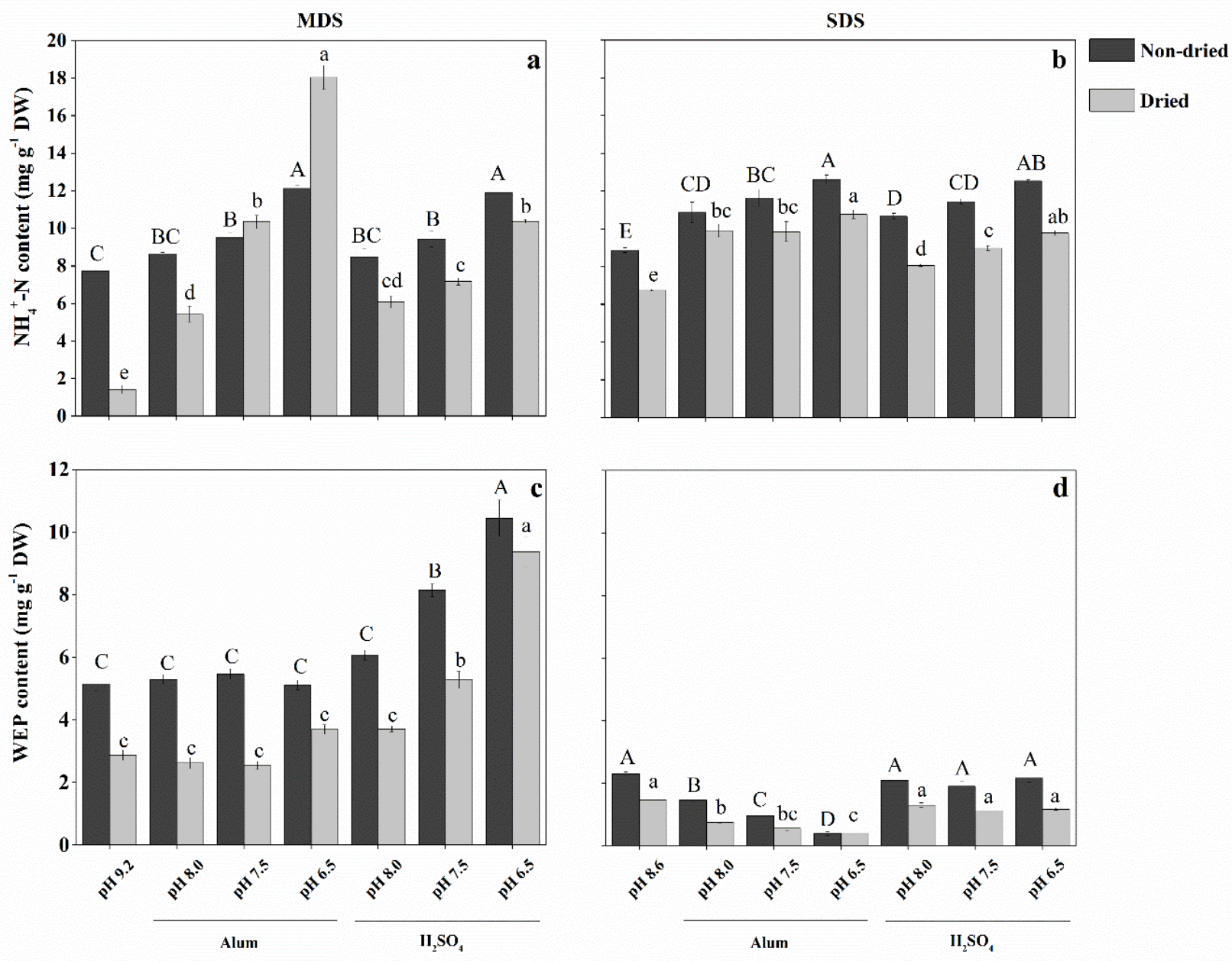

Figure 5. Variations in $\mathrm{NH}_{4}{ }^{+}-\mathrm{N}(\mathbf{a}, \mathbf{b})$ and WEP $(\mathbf{c}, \mathbf{d})$ content between raw and finally dried manure-based (MDS, left) and sewage sludge-based (SDS, right) digestate solids at different acidification levels. Error bars represent standard error $(n=3)$. Different letters denote significant difference $(p<0.05)$ between non-dried treatments (capitals) or between dried treatments (lower case) by Tukey test.

\subsection{Water Extractable P before and after Drying}

Acidification prior to drying affected the WEP content of MDS, but the effects differed with the two agents (Figure $5 \mathrm{c}$ ). Compared with the non-acidified control, using concentrated $\mathrm{H}_{2} \mathrm{SO}_{4}$ significantly increased WEP in raw and dried MD solids by $18-103 \%$ and $29-225 \%$, respectively, and WEP content increased along with the increasing acidification level. Using alum as an acidification agent caused no significant enhancement of WEP in raw and dried MDS solids. Furthermore, drying generally led to considerable WEP reduction (44\%), but acidification using concentrated $\mathrm{H}_{2} \mathrm{SO}_{4}$ decreased the decline to $10-39 \%$ (Figure 5c), being lowest at the highest acidification level.

However, contrary to MDS, acidification using concentrated $\mathrm{H}_{2} \mathrm{SO}_{4}$ before drying had no positive effect on WEP in raw and dried SDS solids compared with the non-acidified control (Figure $5 \mathrm{~d}$ ). Using alum even significantly reduced $(p<0.05)$ the WEP by $37-83 \%$ and $48-72 \%$ in raw and dried SDS solids, respectively, showing an enhanced reduction of 
WEP content with increasing alum addition rate (Figure 5d). Additionally, drying caused an average $36 \%$ decrease of WEP content across SDS treatments.

The different response of WEP content to acidification using concentrated $\mathrm{H}_{2} \mathrm{SO}_{4}$ can probably be attributed to different $\mathrm{P}$ species present in MDS and SDS, respectively. Since MDS is derived from animal manure, a high content of struvite $\left(\mathrm{NH}_{4} \mathrm{MgPO}_{4} \cdot 6 \mathrm{H}_{2} \mathrm{O}\right)$ can be assumed [25], while in SDS produced from anaerobic digestion of sewage sludge, Caphosphates (e.g., $\beta$-tricalciumphosphate, brushite, and dicalciumphosphate) are typically dominant. This is corroborated by the fact that MDS contained twice as much Mg than SDS and a higher Mg/P ratio (MDS, 0.6; SDS, 0.2) while SDS had 53\% more Ca than MDS and also a higher $\mathrm{Ca} / \mathrm{P}$ ratio (MDS, 1.4; SDS, 1.8). The solubility of $\mathrm{Mg}-\mathrm{P}$ and $\mathrm{Ca}-\mathrm{P}$ is $\mathrm{pH}$ dependent; $\mathrm{Mg}-\mathrm{P}$ is fully dissolved at a $\mathrm{pH}$ below 6.7 and Ca-P is mostly dissolved between $\mathrm{pH}$ 6.7-5.5 [26]. In the present study, the digestate solids were not acidified to a $\mathrm{pH}$ lower than 6.5, thus struvite in MDS probably dissolved resulting in higher WEP, and less acid-soluble Ca-P in SDS resulted in a constant level of WEP.

Huang et al. (2007) [27] observed the formation of Ca-P (probably brushite) and Al-P precipitation after adding alum as a stabilizer to sewage sludge using electron microscopy (SEM). Furthermore, alum could lower the solubility and mobility of organic P, e.g., myoinositol hexakisphosphate (phytate), in biosolids by forming an aluminum phytate precipitant [16,28]. Consequently, Huang et al. (2016) [16] showed that soil fertilized with alum-treated poultry litter had $74 \%$ lower WEP than soil receiving untreated litter after 20 years. Moore et al. (2000) [11] reported that alum additions to poultry litter reduced $\mathrm{P}$ runoff by $75 \%$ throughout a three-year trial. However, depending on the $\mathrm{pH}$ level, acidification caused by alum addition could also lead to the dissolution of Mg-P, Al-P and Ca-P, and acid hydrolysis of organic P [27]. Thus, it can be speculated that in MDS, the acidification effect of alum had a similar positive impact on WEP as $\mathrm{H}_{2} \mathrm{SO}_{4}$, but that this effect was counteracted by the addition of $\mathrm{Al}$ with alum $[15,16]$, resulting in a similar WEP content of the non-acidified control and alum-treated MDS. For SDS, acidity created by alum addition did not have an influence on WEP, as also observed with $\mathrm{H}_{2} \mathrm{SO}_{4}$, and the addition of aluminum contributed to the significantly lower WEP in alum-treated SDS.

\subsection{Technology Implementation Options}

Concentrated sulfuric acid $\left(95-98 \% \mathrm{H}_{2} \mathrm{SO}_{4}\right)$ and alum had a market price of around $€ 0.4$ per liter and $€ 135$ per ton, respectively, on chembid.com.

The lowest alum addition rate of $1.2 \%$ (target $\mathrm{pH} 8.0$ ) would result in $5.4 \mathrm{mg} \mathrm{g}^{-1}$ $\mathrm{NH}_{4}{ }^{+}-\mathrm{N}$ in dried MDS (70\% of the initial $\mathrm{NH}_{4}{ }^{+}-\mathrm{N}$ content) at a cost of $€ 1.38$ per ton of MDS, while the minimum concentrated $\mathrm{H}_{2} \mathrm{SO}_{4}$ level $(0.92 \%$, target $\mathrm{pH}$ 8.0) would achieve a similar $\mathrm{NH}_{4}{ }^{+}-\mathrm{N}$ content of $6.1 \mathrm{mg} \mathrm{g}^{-1}$ at a cost of $€ 1.9$ per ton of MDS. If aiming for a higher $\mathrm{NH}_{4}{ }^{+}-\mathrm{N}$ content in dried MDS, using $2 \%$ alum (target $\mathrm{pH} 7.5$ ) or $1.38 \%$ concentrated $\mathrm{H}_{2} \mathrm{SO}_{4}$ (target $\mathrm{pH}$ 6.5) could achieve 10.3 or $10.4 \mathrm{mg} \mathrm{g}^{-1} \mathrm{NH}_{4}{ }^{+}-\mathrm{N}$ at a cost of $€ 2.76$ or $€ 2.85$, respectively.

Regarding SDS, the lowest level of alum addition (0.8\%, target $\mathrm{pH} 8.0)$ could achieve $9.9 \mathrm{mg} \mathrm{g}^{-1} \mathrm{NH}_{4}{ }^{+}-\mathrm{N}$ in dried SDS $\left(12 \%\right.$ higher than the initial $\mathrm{NH}_{4}{ }^{+}-\mathrm{N}$ content $)$ at a cost of $€ 0.56$ per ton, whereas an addition rate of concentrated $\mathrm{H}_{2} \mathrm{SO}_{4}$ of $0.46 \%$ (target $\mathrm{pH} 7.5$ ) would result in $9 \mathrm{mg} \mathrm{g}^{-1} \mathrm{NH}_{4}{ }^{+}-\mathrm{N}$ in dried SDS at a cost of $€ 0.9$ per ton of SDS.

Based on these calculations, using alum would be approximately $30 \%$ cheaper than using $\mathrm{H}_{2} \mathrm{SO}_{4}$ to achieve similar $\mathrm{NH}_{4}{ }^{+}-\mathrm{N}$ contents in dried solids.

\section{Conclusions}

As hypothesized, alum addition $(0.8 \%-4 \%$, target $\mathrm{pH}$ : $8.0,7.5$ and 6.5$)$ significantly increased the $\mathrm{NH}_{4}{ }^{+}-\mathrm{N}$ content in dried MDS and SDS, even more effectively than concentrated $\mathrm{H}_{2} \mathrm{SO}_{4}$, thus raising the level of immediately plant-available $\mathrm{N}$ in the dried products. Contrary to our expectations, alum addition had no considerable influence on WEP in raw and dried MDS, but significantly lowered the WEP in raw and dried SDS. On the other hand, $\mathrm{H}_{2} \mathrm{SO}_{4}$ addition notably increased WEP in raw and dried MDS compared with the 
non-acidified control, yet had no obvious effect on raw and dried SDS. The inorganic $P$ species with different solubility present in solid fractions of organic fertilizers are likely to influence acidification effects on WEP, which also depend on target $\mathrm{pH}$. The present study indicated that acidified-dried digestate solids potentially could become valuable products with high $\mathrm{N}$ fertilizer value and low environmental impact. Furthermore, alum can be considered as effective, low-cost, easy to handle, and a high safety alternative to concentrated $\mathrm{H}_{2} \mathrm{SO}_{4}$ addition before drying of digestate solids.

Author Contributions: Conceptualization, J.L., L.S.J. and D.S.M.-S.; methodology, J.L., L.S.J. and D.S.M.-S.; investigation, J.L.; data curation, J.L.; validation, J.L., L.S.J. and D.S.M.-S.; formal analysis, J.L.; writing—original draft preparation, J.L.; writing—review and editing, J.L., L.S.J. and D.S.M.-S.; visualization, J.L.; supervision, L.S.J. and D.S.M.-S.; project administration, L.S.J.; funding acquisition, J.L. and L.S.J. All authors have read and agreed to the published version of the manuscript.

Funding: This work was financially supported by the University of Copenhagen, Department of Plant and Environmental Sciences, and China Scholarship Council fellowship to the first author.

Data Availability Statement: The data in this study are available upon request.

Acknowledgments: The technical support of Jannie Margrethe Jessen is greatly acknowledged.

Conflicts of Interest: The authors declare no conflict of interest. The funders had no role in the design of the study; in the collection, analyses, or interpretation of data; in the writing of the manuscript, or in the decision to publish the results.

\section{References}

1. Tsui, T.-H.; Wong, J.W.C. A critical review: Emerging bioeconomy and waste-to-energy technologies for sustainable municipal solid waste management. Waste Dispos. Sustain. Energy 2019, 1, 151-167. [CrossRef]

2. Drosg, B.; Fuchs, W.; Al Seadi, T.; Madsen, M.; Linke, B. Nutrient Recovery by Biogas Digestate Processing; IEA Bioenergy: Dublin, Ireland, 2015.

3. Horttanainen, M.; Deviatkin, I.; Havukainen, J. Nitrogen release from mechanically dewatered sewage sludge during thermal drying and potential for recovery. J. Clean. Prod. 2017, 142, 1819-1826. [CrossRef]

4. Pantelopoulos, A.; Magid, J.; Jensen, L.S. Thermal drying of the solid fraction from biogas digestate: Effects of acidification, temperature and ventilation on nitrogen content. Waste Manag. 2016, 48, 218-226. [CrossRef]

5. Roboredo, M.; Fangueiro, D.; Lage, S.; Coutinho, J. Phosphorus dynamics in soils amended with acidified pig slurry and derived solid fraction. Geoderma 2012, 189-190, 328-333. [CrossRef]

6. Sommer, S.G.; Hjorth, M.; Leahy, J.J.; Zhu, K.; Christel, W.; Sørensen, C.G.; Sutaryo, S. Pig slurry characteristics, nutrient balance and biogas production as affected by separation and acidification. J. Agric. Sci. 2015, 153, 177-191. [CrossRef]

7. Choi, I.H.; Moore, P.A. Effect of Various Litter Amendments on Ammonia Volatilization and Nitrogen Content of Poultry Litter. J. Appl. Poult. Res. 2008, 17, 454-462. [CrossRef]

8. Spiehs, M.J.; Woodbury, B.L. Use of aluminum sulfate (alum) as a feedlot surface amendment to reduce ammonia emissions from beef feedlots. In Proceedings of the 2018 ASABE Annual International Meeting, Detroit, MI, USA, 29 July-1 August 2018 ; American Society of Agricultural and Biological Engineers: St. Joseph, MI, USA, 2018; p. 1. [CrossRef]

9. Bautista, J.M.; Kim, H.; Ahn, D.-H.; Zhang, R.; Oh, Y.-S. Changes in physicochemical properties and gaseous emissions of composting swine manure amended with alum and zeolite. Korean J. Chem. Eng. 2011, 28, 189-194. [CrossRef]

10. Moore, P.A.; Miller, D.M. Decreasing Phosphorus Solubility in Poultry Litter with Aluminum, Calcium, and Iron Amendments. J. Environ. Qual. 1994, 23, 325-330. [CrossRef]

11. Moore, P.A.; Daniel, T.C.; Edwards, D.R. Reducing Phosphorus Runoff and Inhibiting Ammonia Loss from Poultry Manure with Aluminum Sulfate. J. Environ. Qual. 2000, 29, 37-49. [CrossRef]

12. Zhang, H.-F.; Jiao, H.-C.; Song, Z.-G.; Lin, H. Effect of Alum-Amended Litter and Stocking Density on Ammonia Release and Footpad and Hock Dermatitis of Broilers. Agric. Sci. China 2011, 10, 777-785. [CrossRef]

13. Delaune, P.B.; Moore, P.A.; Daniel, T.C.; Lemunyon, J.L. Effect of Chemical and Microbial Amendments on Ammonia Volatilization from Composting Poultry Litter. J. Environ. Qual. 2004, 734, 728-734. [CrossRef]

14. Lefcourt, A.; Meisinger, J. Effect of Adding Alum or Zeolite to Dairy Slurry on Ammonia Volatilization and Chemical Composition. J. Dairy Sci. 2001, 84, 1814-1821. [CrossRef]

15. Moore, P.A.; Edwards, D.R. Long-Term Effects of Poultry Litter, Alum-Treated Litter, and Ammonium Nitrate on Phosphorus Availability in Soils. J. Environ. Qual. 2007, 36, 163-174. [CrossRef] [PubMed]

16. Huang, L.; Moore, P.A.; Kleinman, P.J.A.; Elkin, K.R.; Savin, M.C.; Pote, D.H.; Edwards, D.R. Reducing Phosphorus Runoff and Leaching from Poultry Litter with Alum: Twenty-Year Small Plot and Paired-Watershed Studies. J. Environ. Qual. 2016, 45, 1413-1420. [CrossRef] 
17. Liu, J.; de Neergaard, A.; Jensen, L.S. Increased retention of available nitrogen during thermal drying of solids of digested sewage sludge and manure by acid and zeolite addition. Waste Manag. 2019, 100, 306-317. [CrossRef]

18. Sommer, S.; Zhang, G.; Bannink, A.; Chadwick, D.; Misselbrook, T.; Harrison, R.; Hutchings, N.; Menzi, H.; Monteny, G.; Ni, J.; et al. Algorithms Determining Ammonia Emission from Buildings Housing Cattle and Pigs and from Manure Stores. Adv. Agron. 2006, 89, 261-335. [CrossRef]

19. Petrovic, J.; Thomas, G. Reaction of Aluminum with Water to Produce Hydrogen: A Study of Issues Related to the Use Aliminum for On-Board Vehicular Hydrogen Storage; US Department of Energy: Washington, DC, USA, 2008; pp. 1-26.

20. Haghi, A.K.; Ghanadzadeh, H. A study of thermal drying process. Indian J. Chem. Technol. 2005, 12, $654-663$.

21. Fangueiro, D.; Hjorth, M.; Gioelli, F. Acidification of animal slurry-A review. J. Environ. Manag. 2015, 149, 46-56. [CrossRef]

22. McCrory, D.F.; Hobbs, P. Additives to Reduce Ammonia and Odor Emissions from Livestock Wastes: A Review. J. Environ. Qual. 2001, 30, 345-355. [CrossRef]

23. Dai, X.; Blanes-Vidal, V. Emissions of ammonia, carbon dioxide, and hydrogen sulfide from swine wastewater during and after acidification treatment: Effect of $\mathrm{pH}$, mixing and aeration. J. Environ. Manag. 2013, 115, 147-154. [CrossRef]

24. Petersen, S.O.; Andersen, A.J.; Eriksen, J. Effects of Cattle Slurry Acidification on Ammonia and Methane Evolution during Storage. J. Environ. Qual. 2012, 41, 88-94. [CrossRef] [PubMed]

25. Pagliari, P.H. Variety and Solubility of Phosphorus Forms in Animal Manure and Their Effects on Soil Test Phosphorus. In Applied Manure and Nutrient Chemistry for Sustainable Agriculture and Environment; Springer Science and Business Media LLC: Berlin/Heidelberg, Germany, 2014; pp. 141-161.

26. Fordham, A.W.; Schwertmann, U. Composition and Reactions of Liquid Manure (Gülle), with Particular Reference to Phosphate: II. Solid Phase Components. J. Environ. Qual. 1977, 6, 136-140. [CrossRef]

27. Huang, X.-L.; Chen, Y.; Shenker, M. Solid Phosphorus Phase in Aluminum- and Iron-Treated Biosolids. J. Environ. Qual. 2007, 36, 549-556. [CrossRef] [PubMed]

28. Yan, Y.; Li, W.; Yang, J.; Zheng, A.; Liu, F.; Feng, X.; Sparks, D.L. Mechanism of Myo-inositol Hexakisphosphate Sorption on Amorphous Aluminum Hydroxide: Spectroscopic Evidence for Rapid Surface Precipitation. Environ. Sci. Technol. 2014, 48, 6735-6742. [CrossRef] 